\section{Bills pass at last minute}

\section{Washington}

BEFORE rushing home last week for election campaigns, congressional legislators passed some key science bills in a flurry of last-minute voting, but left others to expire when the 101st Congress formally concludes in January.

Top of the list of successes was the passage of the Clean Air Act, after a decade of hard-fought lobbying by environmentalists. The new law will phase out ozone-destroying chlorofluorocarbons (CFCs) over the next decade, eliminating them completely by 2000 . CFC substitutes, which are less harmful but still deplete ozone and contribute to the greenhouse effect, will be phased out by 2030. New automobile emission standards will cut hydrocarbon emissions by 35 per cent and nitrogen oxide output by 60 per cent. Smoke-stack emissions will be regulated to reduce sulphur dioxide and nitrogen oxide and decrease acid rain.

Many of the elements of the measure will have global, as well as local, impact, says Richard Ayres, an attorney for the Natural Resources Defence Council. Improved automobile efficiency reduces total US carbon dioxide emissions, and encourages other countries to follow suit with high-mileage cars aimed at the US market. "There's a real international effect from these national standards", he says.

On the research front, the surprise loser was legislation that would have made it a federal crime to break into an animalresearch laboratory (see Nature 344, 96; 1990). Although one bill had already been passed by the senate and another by Representative Charles Stenholm (Democrat, Texas) appeared on the verge of passage in the house, "we just ran out of time", says Barbara Rich, a National Association for Biomedical Research lobbyist. Similar bills will be reintroduced early next year, but animal activists are promising a stiffer fight, and prospects of quick passage are slim.

For biotechnology, modification to the orphan drug act was the only significant legislation to emerge. The 1983 Act gave companies financial perks and exclusive marketing rights for drugs that would probably be otherwise unprofitable, due to their small potential markets (see Nature 345, 759; 1990). But critics complained that it was virtually a licence to print money for some fortunate companies, whose drugs became unexpectedly profitable after they had already been designated "orphans."

Early in the year, Henry Waxman (Democrat, California) introduced a bill that would modify the act by making orphan status rescindable when drugs become money-makers on their own and allowing some competition between companies who were developing drugs concurrently. Despite objections from some companies that he was changing the rules in the middle of the game, Waxman compromised only enough to include a clause for companies with orphan drugs already on the market or in the pipeline. The bill, which leaves untouched the blockbuster drugs that sparked off the controversy, will now become law.

Two legislative proposals, a fetal tissue research bill (see Nature 346, 598; 1990) and the Human Genome Privacy Act (see Nature 347, 221; 1990), were introduced at the eleventh hour. A proposal to end the indefinite moratorium on federally funded fetal tissue research failed to be passed - due to Congress's inability or unwillingness to deal with the issue of fetal tissue transplantation research. It will be taken up again in January 1991.

The Human Genome Privacy Act, a bill proposed by Representative John Conyers (Democrat, Michigan) to prevent government disclosure of genetic information to third parties without the individual's consent, may fare better. It is backed by a broad coalition of scientists, ethicists and religious leaders, and will be reintroduced next year, his staff says.

Christopher Anderson \& Diane Gershon

\title{
Harnessing northern lights
}

\section{Washington}

IMAGINE this: A powerful US senator puts $\$ 9$ million dollars in next year's budget for your university's research and gives you a $\$ 25$ million supercomputer. But then he

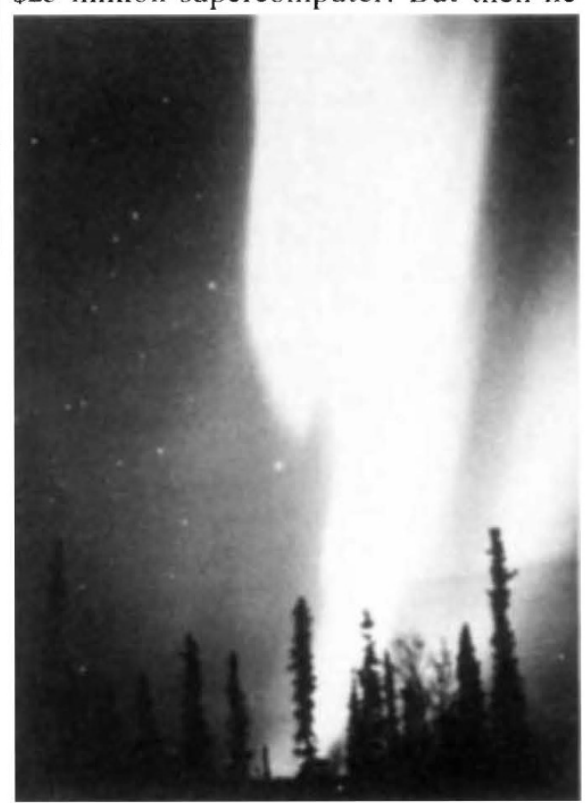

The aurora borealis (or northern lights).

specifies that you use the money and the machine for an impossible project: to tap the energy of the aurora borealis to provide clean power and fight global warming. "Harness the electrojet - this inexhaustible supply energy in space -and bring it to earth", he asks.

This nightmare of pork-barrel politics became a reality for the University of Alaska's Geophysical Institute last month when Senator Ted Stevens' (Republican, Alaska) auroral-research proposal slipped past Congress in the final stages of the budget process. Scientifically, admits Geophysical Institute director Syun Akasofu with some understatement, extracting energy from the northern lights is "a dream". Still, \$34 million is a hard gift to refuse. After some thought, Akasofu and his staff came up with an idea that would enable them to accept the money with clean consciences. Noting that the aurora is created when charged particles are captured by the Earth's magnetic field, Akasofu issued a statement last week saying that, "What the Senator means by 'bringing aurora energy down to the ground' is to 'bring the knowledge of auroral research to accelerate fusion energy research"..

Knowledge of magnetically steered plasmas is needed both to understand the aurora and to build a fusion machine, Akasofu points out. Thanks to $\$ 10$ million received with Stevens' help last year, his institute is already at work on a highpowered radio transmitter that may be able to modulate the aurora so that it acts as a huge low-frequency antenna. (The plan is to use the antenna so that the Navy can communicate with its submarines while they are underwater.) Modulating one kind of plasma is not so different from controlling another, Akasofu says, adding that his centre has collaborated with fusion scientists from the Princeton Plasma Physics Laboratory and Los Alamos National Laboratory. "We're trying to understand the basic nature of hydrogen plasma - surely that will help the fusion people", he says.

But Akasofu may still have some trouble getting his money. In the closing hours of the budget appropriations process last week. Senator Sam Nunn (Democrat, Georgia), the powerful head of the defence committee, attacked porkbarrel projects in the defence budget, and promised to hold hearings to review them early next year. "I intend to hear directly from the Secretary of Defence, to determine his views on each and every one of the earmarked projects", he warned.

Christopher Anderson 